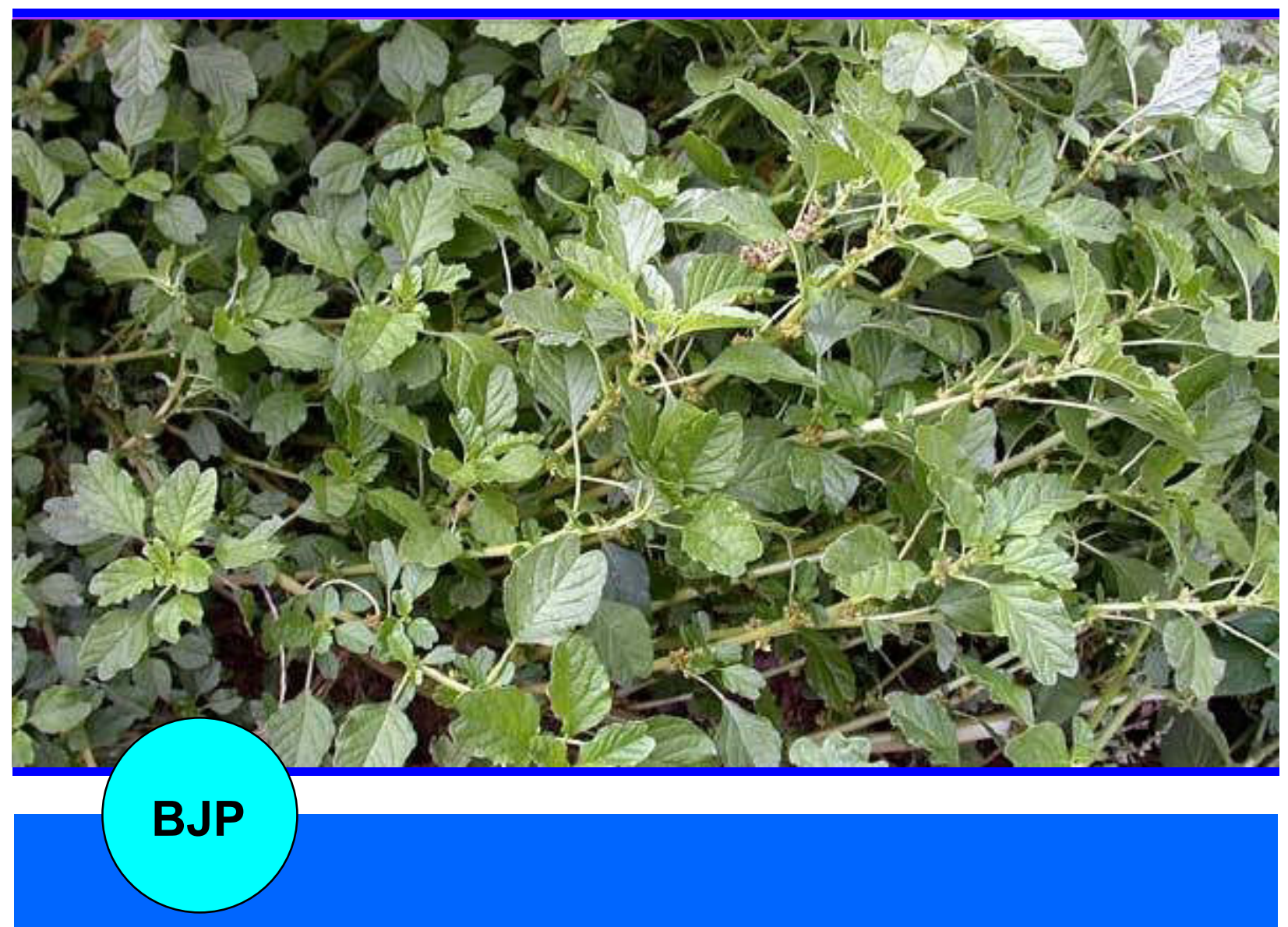

Bangladesh Journal of Pharmacology

Research Article

Amelioration of isoniazid and rifampicin-induced liver toxicity by Amaranthus graecizans subsp. silvestris in rat 
Abstracted/indexed in Academic Search Complete, Asia Journals Online, Bangladesh Journals Online, Biological Abstracts, BIOSIS Previews, CAB Abstracts, Current Abstracts, Directory of Open Access Journals, EMBASE/Excerpta Medica, Global Health, Google Scholar, HINARI (WHO), International Pharmaceutical Abstracts, Open J-gate, Science Citation Index Expanded, SCOPUS and Social Sciences Citation Index;

ISSN: $1991-0088$

\title{
Amelioration of isoniazid and rifampicin-induced liver toxicity by Amaranthus graecizans subsp. silvestris in rat
}

\author{
Saiqa Ishtiaq, Muhammad Shaharyar Khan Afridi and Nawal Masood
}

Punjab University College of Pharmacy, University of the Punjab, Allama lqbal Campus, Lahore 54000, Pakistan.

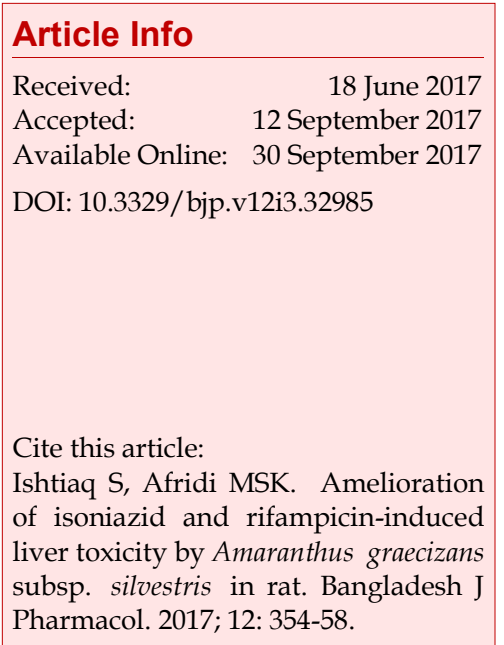

\begin{abstract}
Amaranthus graecizans subsp. silvestris, a folk medicine for the treatment of inflammation, was used to evaluate its hepatoprotective potential against rifampicin and isoniazid-induced liver damage. Wistar albino rats were divided into four groups: Group I served as control (distilled water treated), Group II served as hepatotoxic group (isoniazid $50 \mathrm{mg} / \mathrm{kg}$ and rifampicin 100 $\mathrm{mg} / \mathrm{kg}$, treated), Group III served as positive control (silymarin $100 \mathrm{mg} / \mathrm{kg}$, treated) while Group IV served as A. graecizans subsp. silvestris extract (400 $\mathrm{mg} / \mathrm{kg}$ ) treated group. The results suggest that the liver markers (alanine aminotransferase, aspartate aminotransferase, alkaline phosphatase and total bilirubin) were significantly increased in the animals of Group II. The methanolic extract showed a significant decrease in the raised liver enzymes of Group IV and encountered the liver damage caused by isoniazid and rifampicin. Histopathological examination of liver also revealed the improved architecture in the extract-treated group. Thus, the methanolic extract has potential liver protective action due to its phytochemicals.
\end{abstract}

\section{Introduction}

Directly observed treatment short course (TB-DOTS) with isoniazid, rifampicin and pyrazinamide are highly effective treatment for the management of tuberculosis. Both isoniazid and rifampicin are well documented for their hepatotoxicity. Isoniazid produces liver injury by producing reactive toxic metabolites (isonicotinic acid, and hydrazine and acetylhydrazine free radical) that interacts with the liver proteins and results into anomaly of the liver anatomy. On the other hand, rifam -picin when given in combination with isoniazid causes cytochrome $\mathrm{P}_{450}$ enzyme-induction and results in the increased metabolism of isoniazid (Gangadharam, 1986; Wang et al., 2016; Pandit et al., 2012).

The animal model of hepatotoxicity is usually produced by either paracetamol or carbon tetrachloride. Then, different plants are examined to see their hepatoprotec- tive effects (Qadir and Ahmad, 2017). However, antitubercular drugs-induced hepatotoxicity and the effect of the plant to overcome it is observed only in a few plants such as Monotheca buxifolia (Ullah et al., 2016), Moringa oleifera (Pari and Kumar, 2004).

Amaranthus graecizans subsp. silvestris (Vill.) Brenan, also known as "Mediterranean amaranth", belongs to the family Amaranthaceae, occurs in the warmer parts of Europe to the cooler regions of Western Asia and North Western India, also found in tropical Africa (Flora of Pakistan, 1972). It is considered as a wild food plant, semi-cultivated in Africa and consumed as a vegetable (Tabuti, 2007). It is also used as a folk medicine. The young leaves and shoot of the plant either boiled or steamed are employed to treat sore throat, as an immune system booster and to relieve joint pain by the natives in Uganda. The adverse effect associated with its use is the throat irritation (Nabatanzi 
and Nakalembe, 2016). In Pakistan, it is called 'Phulari' by the natives and it is predominantly northerly distributed. The leaves of the plant are used to treat inflammation, piles and gonorrhea (Hussain et al., 2010; Arshad et al., 2011; Nisar et al., 2011). The plant possesses remarkable anti-oxidant properties that make it a suitable candidate to counter oxidative stress (Ishtiaq et al., 2014). The methanolic extract of the herb is also reported to have significant analgesic and antiinflammatory action which ensures the promising antioxidant abilities. The plant has also shown anti-cholinesterase and anti-protease activity (Ishtiaq et al., 2017).

Oxidative stress is one of the main reason behind multiple degenerative diseases including liver damage. Parenchymal cells are primary cells subjected to oxidative stress-induced injury in the liver (Li et al., 2015). As, it plays a core role in liver aberrations and their progression, the utilization of herbal drugs with anti-oxidant potentials have been suggested as healing agents, as well as adjuncts, to neutralize liver damage (Casas-Grajales and Muriel, 2015). With this view, the present project was designed to evaluate hepatoprotective potential of Amaranthus graecizans subsp. silvestris, against isoniazid and rifampicin-induced liver toxicity in Wistar rats.

\section{Materials and Methods}

\section{Chemicals}

Methanol, isoniazid and rifampicin were procured from the Pacific Pharmaceuticals Ltd. Lahore. Diagnostic kits of transaminases, alkaline phosphatase and bilirubin were obtained from the Global (UK). Silymarin was acquired from the Wilson's Healthcare, Pakistan. All the chemicals were of analytical grade and reagents were freshly prepared in the laboratory.

\section{Plant material}

Fresh plant parts were collected from the Chakwal and authenticated by Dr. Muhammad Ajaib, Department of Botany, Mirpur University of Sciences and Technology, Pakistan against voucher specimen of GC. Herb. 2329. The collected material was cleaned, dried and then powdered and preserved in amber colored bottles.

\section{Animal}

Wistar rats of either sex were purchased from the University of Veterinary and Animal Sciences, Lahore Pakistan. The animals were kept at room temperature $25^{\circ} \mathrm{C}$ under 12 hours of dark and light cycles. The animals were fed with the standard pelleted diet with water ad libitum.

\section{Preparation of methanolic extract}

The powder $(500 \mathrm{~g})$ was macerated in $700 \mathrm{~mL}$ of $90 \%$ methanol for seven days. The macerated material was shaken periodically to facilitate extraction. After seven days, the sample solution was first filtered through Whatman No. 1 filter paper. The extract was evaporated using the rotary evaporator at a temperature lower than $40^{\circ} \mathrm{C}$. The extract was collected and stored in an airtight container which was placed in the refrigerator for further investigations (Miliauskas et al., 2004).

\section{Phytochemical screening}

The phytochemical analysis was carried out according to the standard procedures (Akbar et al., 2014).

\section{Study design}

The study was conducted for 21 days. The weight of the rat was between 150-200 g. Twenty animals were randomly divided into four groups $(n=5)$. Group I was given with distilled water as a control. Group II was administered with isoniazid (50 $\mathrm{mg} / \mathrm{kg}$ ) and rifampicin $(100 \mathrm{mg} / \mathrm{kg})$. Group III was treated with silymarin (100 $\mathrm{mg} / \mathrm{kg}$ ), isoniazid (50 mg/ kg) and rifampicin (100 mg/ $\mathrm{kg}$ ). Group IV was treated with $A$. graecizans subsp. silvestris (400 mg/kg), INH (50 mg/kg) and RMP (100 $\mathrm{mg} / \mathrm{kg})$.

All the treatment groups were administered orally in distilled water $(10 \mathrm{~mL} / \mathrm{kg})$ for 21 days. At the end of the treatment, animals were anesthetized by i.p. administration of $5 \mathrm{~mL} / \mathrm{kg}$ of a solution of $1 \%$ chloralose in $25 \%$ urethane $(\mathrm{w} / \mathrm{v})$. Blood samples of animals were collected by cardiac puncture in sterile heparinized tubes and allowed to clot for $30 \mathrm{~min}$. Serum was separated and used for the assay of serum marker enzymes (Salama et al., 2013).

\section{Histopathological examination}

Fresh liver tissues (previously trimmed to $7 \mu \mathrm{m}$ thick) were placed in plastic cassettes and immersed in neutral buffered formalin for 24 hours. Fixed tissues were processed routinely and then fixed in paraffin, sectioned, deparaffinized and rehydrated. The tissues were then stained with eosin and hematoxylin. The extent of combinational necrosis of isoniazid and rifampicin was evaluated by structural changes in liver sections stained with hematoxylin and eosin (Habbu et al., 2008).

\section{Statistical analysis}

The values are expressed as mean \pm SEM. SPSS 21 was used for the statistical analysis. Statistical significance of the differences between control and treated groups was calculated using One-way ANOVA with post-hoc Student's t-test. $\mathrm{p}<0.05$ was considered to be significant.

\section{Results}

\section{Phytochemical analysis}

Phytochemical screening revealed the presence of alkaloids, carbohydrates, saponins, flavonoids, phenols, 
Table I

\section{Effects of extract on the liver markers}

\begin{tabular}{|llcccc|} 
Group & & $\begin{array}{c}\text { Alanine transami- } \\
\text { nase }(\mu / \mathrm{L})\end{array}$ & $\begin{array}{c}\text { Aspartate trans- } \\
\text { aminase }(\mu / \mathrm{L})\end{array}$ & $\begin{array}{c}\text { Alkaline phos- } \\
\text { phatase }(\mu / \mathrm{L})\end{array}$ & $\begin{array}{c}\text { Total bilirubin }(\mathrm{mg} / \\
\mathrm{dL})\end{array}$ \\
\hline I & Control & $23.8 \pm 2.1$ & $20.6 \pm 1.2$ & $50.9 \pm 0.6$ & $2.1 \pm 0.5$ \\
II & $\begin{array}{l}\text { Isoniazid }(50 \mathrm{mg} / \mathrm{kg}) \text { plus } \\
\text { rifampicin } 100 \mathrm{mg} / \mathrm{kg})\end{array}$ & $49.1 \pm 4.4^{\mathrm{a}}$ & $45.2 \pm 4.8^{\mathrm{a}}$ & $124.6 \pm 19.5^{\mathrm{a}}$ & $4.4 \pm 0.1^{\mathrm{a}}$ \\
& & & & \\
III & Silymarin $(100 \mathrm{mg} / \mathrm{kg})$ & $36.3 \pm 1.7^{\mathrm{b}}$ & $40.6 \pm 3.5$ & $56.7 \pm 0.8^{\mathrm{b}}$ & $1.3 \pm 0.2^{\mathrm{b}}$ \\
IV & Extract $(400 \mathrm{mg} / \mathrm{kg})$ & $24.7 \pm 2.9 \mathrm{~b}$ & $26.4 \pm 1.7^{\mathrm{b}}$ & $48.1 \pm 0.9^{\mathrm{b}}$ & $1.9 \pm 0.1^{\mathrm{b}}$ \\
\hline
\end{tabular}

All groups are compared with Group II using SPSS by applying one way ANOVA. arepresents significance level of $p<0.05$. bsignificant $p$ value comparison of Group II with Group III and Group IV

\begin{tabular}{|c|c|c|c|c|c|c|c|c|}
\hline \multicolumn{9}{|c|}{ Table II } \\
\hline \multicolumn{9}{|c|}{ Histopathological examinations of livers of different treatment groups } \\
\hline Groups & Portal area & $\begin{array}{l}\text { Cell balloon- } \\
\text { ing degener- } \\
\text { ation }\end{array}$ & Cytoplasm & $\begin{array}{l}\text { Canaliculi } \\
\text { cholestasis }\end{array}$ & Necrosis & $\begin{array}{l}\text { Vascu- } \\
\text { lar } \\
\text { injury }\end{array}$ & $\begin{array}{l}\text { Stea- } \\
\text { tosis }\end{array}$ & $\begin{array}{c}\text { Interface } \\
\text { hepatitis } \\
\text { fibrosis }\end{array}$ \\
\hline I & Normal & - & Normal & - & - & - & - & - \\
\hline II & $\begin{array}{l}\text { Portal area ex- } \\
\text { pansion } \\
\text { (moderate) }\end{array}$ & Mild & $\begin{array}{l}\text { Cytoplasmic } \\
\text { degeneration } \\
\text { (Mild) }\end{array}$ & Mild & $\begin{array}{l}\text { Mild } \\
\text { necrotic } \\
\text { tissue }\end{array}$ & - & - & - \\
\hline III & $\begin{array}{l}\text { Bile duct } \\
\text { proliferation } \\
\text { (Mild) }\end{array}$ & - & $\begin{array}{l}\text { Cytoplasmic } \\
\text { ballooning } \\
\text { (mild) }\end{array}$ & - & - & - & - & - \\
\hline IV & Normal & - & Normal & Mild & - & - & - & - \\
\hline
\end{tabular}
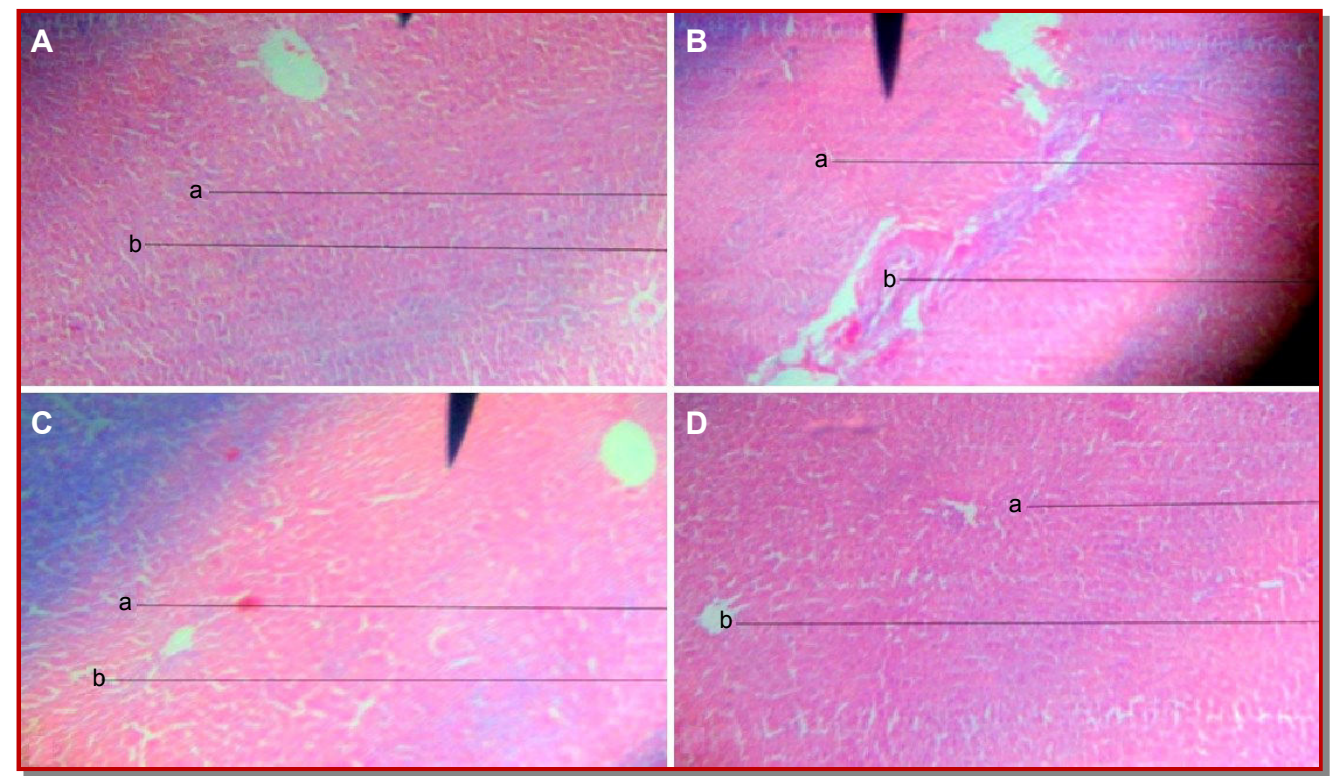

Figure 1: A) Control group a: Normal hepatocytes b: Normal sinusoids, B) Toxic group a: Cytoplasmic degeneration b: Portal vein expansion, C) Standard group a: Normal hepatocytes b: Normal sinusoids, D) Experimental group a: Normal hepatocytes b: Normal portal vein

steroids and glycosides in the extract whereas proteins and triterpenoids were absent.

\section{Hepatoprotective activity}

The hepatoprotective activity of the extract showed significant $\mathrm{p}<0.05$ reduction in aminotransferases, alkaline phosphatases and total bilirubin levels. Significant results were also obtained with silymarin but the more pronounced hepatoprotective effect was observed with 
the methanolic extract (Table I).

\section{Histopathological examination}

The histopathological examination also showed less damage to the hepatocytes and liver architecture in methanolic extract and silymarin treated groups when compared with isoniazid $(50 \mathrm{mg} / \mathrm{kg}$ and rifampicin $(100 \mathrm{mg} / \mathrm{kg}$ ) treated group (Figure 1). The detailed histopathological observations were tabulated (Table II).

\section{Discussion}

Methanolic extract of A. graecizans subsp. silvestris was evaluated for its hepatoprotective potentials against the combination of isoniazid and rifampicin. It was observed that the methanolic extract of A. graecizans subsp. silvestris, significantly $(\mathrm{p}<0.05)$ reduced the liver profile parameters (ALT, AST, ALP and total bilirubin) and showed the protection of hepatocytes against isoniazid- and rifampicin-induced liver injury when compared with the hepatotoxic group. The histopathological assessment also revealed the regeneration of hepatocytes against the destruction caused by these anti -tubercular agents.

The hepatoprotective activity of the plant extract could be due to the presence of the alkaloids, saponins, phenolic compounds, tannins, flavonoids and steroids (Agbafor et al., 2014).

The basic phytochemical group screening of the $A$. graecizans subsp. silvestris also unveiled the occurrence of alkaloids, carbohydrates, saponins, flavonoids, phenol, steroids, and glycosides in the sample whereas proteins and triterpenoids were absent.

This variety of phytochemicals in the extract may produce their hepatoprotective effect either by preventing or scavenging the free radicals generated as it holds appreciable anti-oxidant activity (Ishtiaq et al., 2014) or through an enhanced protein synthesis as observed in histopathological sections of the liver. The extract may also increase the excretion of isiniazid and rifampicin.

A number of plants, containing these phytochemicals demonstrated hepatoprotective effects in various researches when evaluated. Various plants i.e. Celosia cristata and Bupleurum scorzonerifolium are the rich source of saponins, has shown to exhibit hepatoprotective effect (Wang et al., 2010; Matsuda et al., 1997). Similarly, the plants enrich with flavonoids and phenolic acids i.e. Equisetum arvense and Laggera alata, also possess hepatoprotectant potentials (Wu et al., 2006; Oh et al., 2004). Quercetin is a flavonoid, when it's given to hepatocompromized rats, it results in the lowering of elevated hepatic enzyme levels (Janbaz et al., 2004). Certain plants i.e. Hyperricum erectum, Sarcandra glabra etc. with hepatoprotective glycosides are also reported in the literature (An et al., 2009; Li et al., 2006).

\section{Conclusion}

A. graecizans subsp. silvestris showed the presence of alkaloids, carbohydrates, saponins, flavonoids, phenol, steroids, and glycosides. The methanolic extract showed hepatoprotective action in rat model against isoniazid plus rifampicin-induced hepatotoxicity.

\section{Ethical Issue}

The protocols followed to carry out the project was approved by the Animal Ethical Committee of Punjab University College of Pharmacy, prepared by National Institute of Health (AEC/ PUCP/1041/4313).

\section{Conflict of Interest}

We declare that we have no conflict of interest.

\section{Acknowledgement}

The current research project was funded by Punjab University College of Pharmacy, University of the Punjab, Lahore Pakistan. The authors are thankful to Dr. Sairah Hafeez Kamran, for their support and suggestions regarding the study.

\section{References}

Agbafor KN, Ogbanshi ME, Akubugwo EI. Phytochemical screening, hepatoprotective and antioxidant effects of leaf extracts of Zapoteca portoricensis. Adv Biol Chem. 2014; 4: 3539.

Akbar S, Hanif U, Ali J, Ishtiaq S. Pharmacognostic studies of stem, roots and leaves of Malva parviflora L. Asian Pacific J Trop Biomed. 2014; 4: 410-15.

An RB, Jeong GS, Beom JS, Sohn DH, Kim YC. Chromone glycosides and hepatoprotective constituents of Hypericum erectum. Archives Pharmacal Res. 2009; 32: 1393-97.

Arshad M, Nisar MF, Majeed A, Ismail S, Ahmad M. Ethnomedicinal flora in district Sialkot, Punjab, Pakistan. Middle East J Sci Res. 2011; 9: 209-14.

Casas-Grajales S, Muriel P. Anti-oxidants in liver health. World J Gastrointest Pharmacol Ther. 2015; 6: 59-72.

Gangadharam PRJ. Isoniazid, rifampin, and hepatotoxicity. Am Rev Respir Dis. 1986; 133: 963-65.

Habbu P, Shastry R, Mahadevan KM, Joshi H, Das S. Hepatoprotective and anti-oxidant effects of Argyreia 
Speciosa in rats. Afr J Tradit Complement Altern Med. 2008; 5: 158-64.

Hussain K, Nisar MF, Majeed A, Nawaz K, Bhatti KH. Ethnomedicinal survey for important plants of Jalalpur Jattan, district Gujrat, Punjab, Pakistan. Ethnobotanical Leaflets. 2010; 7: 807-25.

Ishtiaq S, Ahmad M, Hanif U, Akbar S, Kamran SH. Phytochemical and in vitro anti-oxidant evaluation of different fractions of Amaranthus graecizans subsp. silvestris (Vill.) Brenan. Asian Pacific J Trop Med. 2014; 7: S342-47.

Ishtiaq S, Ali T, Ahmad B, Anwar F, Afridi MSK, Shaheen H. Phytochemical and biological evaluations of methanolic extract of Amaranthus graecizans subsp. silvestris (Vill.) Brenan. Br J Pharm Res. 2017; 15: 1-11.

Janbaz KH, Saeed SA, Gilani AH. Studies on the protective effects of caffeic acid and quercetin on chemical-induced hepatotoxicity in rodents. Phytomedicine 2004; 11: 424-30.

Li S, Tan HY, Wang N, Zhang ZJ, Lao L, Wong CW, Feng Y. The role of oxidative stress and anti-oxidants in liver diseases. Int J Mol Sci. 2015; 16: 26087-124.

Li Y, Zhang DM, Li JB, Yu SS, Li Y, Luo YM. Hepatoprotective sesquiterpene glycosides from Sarcandra glabra. J Natural Prod. 2006; 69: 616-20.

Matsuda H, Murakami T, Ninomiya $K$, Inadzuki $M$, Yoshikawa M. New hepatoprotective saponins, bupleurosides III, VI, IX, and XIII, from Chinese Bupleuri Radix: Structure-requirements for the cytoprotective activity in primary cultured rat hepatocytes. Bioorg Med Chem Lett. 1997; 7: 2193-98.

Miliauskas G, Venskutonis PR, Van Beek TA. Screening of radical scavenging activity of some medicinal and aromatic plant extracts. Food Chem. 2004; 85: 231-37.

Nabatanzi A, Nakalembe I. Wild food plants used by people living with HIV/AIDS in Nakisunga sub-county, Uganda. Afr J Food Agric Nutr Dev. 2016; 16: 11310-30.

Nisar MF, Ismail S, Arshad M, Majeed A, Arfan M. Ethnome- dicinal flora of district Mandi Bahaudin, Pakistan. Middle East J Sci Res. 2011; 9: 233-38.

Oh H, Kim DH, Cho JH, Kim YC. Hepatoprotective and free radical scavenging activities of phenolic petrosins and flavonoids isolated from Equisetum arvense. J Ethnopharmacol. 2004; 95: 421-24.

Pakistan: Flora of Pakistan, 1972; Retrieved from: http:// www.efloras.org/florataxon.aspx? flora_id=5\&taxon_id =250064259. Retrieved on: April 30, 2017.

Pandit A, Sachdeva T, Bafna P. Drug-induced hepatotoxicity: A review. J Appl Pharm Sci. 2012; 2: 233-43.

Pari L, Kumar NA. Hepatoprotective activity of Moringa oleifera on antitubercular drug-induced liver damage in rats. J Med Food. 2004; 5: 171-77.

Qadir M, Ahmad Z. Advances in hepatoprotective medicinal plants research. Bangladesh J Pharmacol. 2017; 12: 229-42.

Salama SM, Abdulla MA, AlRashdi AS, Ismail S, Alkiyumi SS, Golbabapour S. Hepatoprotective effect of ethanolic extract of Curcuma longa on thioacetamide-induced liver cirrhosis in rats. BMC Complement Altern Med. 2013; 13: 56.

Tabuti JRS. Status of non-cultivated food plants in Bulamogi County, Uganda. Afr J Ecol. 2007; 45: 96-101.

Ullah I, Khan J, Adhikari A, Shahid M. Hepatoprotective effect of Monotheca buxifolia fruit against antitubercular drugsinduced hepatotoxicity in rats. Bangladesh J Pharmacol. 2016; 11: 248-56.

Wang P, Pradhan K, Zhong XB, Ma X. Isoniazid metabolism and hepatotoxicity. Acta Pharm Sin B. 2016; 6: 384-92.

Wang Y, Lou Z, Wu QB, Guo ML. A novel hepatoprotective saponin from Celosia cristata L. Fitoterapia 2010; 81: 1246-52.

Wu Y, Wang F, Zheng Q, Lu L, Yao H, Zhou C, Wu X, Zhao Y. Hepatoprotective effect of total flavonoids from Laggera alata against carbon tetrachloride-induced injury in primary cultured neonatal rat hepatocytes and in rats with hepatic damage. J Biomed Sci. 2006; 13: 569-78.

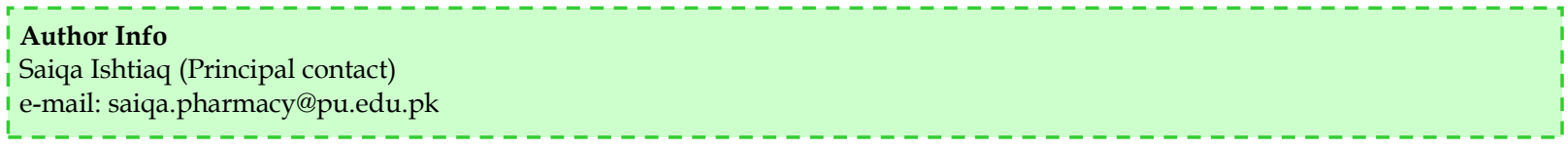

